\title{
Correction to: Optimal design for disc golf by computational fluid dynamics and machine learning
}

\author{
Eero Immonen ${ }^{1}$ (1)
}

Published online: 19 January 2022

(c) The Author(s) 2022

\section{Correction to: \\ Structural and Multidisciplinary Optimization (2021) 65:12 \\ https://doi.org/10.1007/s00158-021-03107-7}

The original article was published online without open access grants.

The original article has been corrected.

Open Access This article is licensed under a Creative Commons Attribution 4.0 International License, which permits use, sharing, adaptation, distribution and reproduction in any medium or format, as long as you give appropriate credit to the original author(s) and the source, provide a link to the Creative Commons licence, and indicate if changes were made. The images or other third party material in this article are included in the article's Creative Commons licence, unless indicated otherwise in a credit line to the material. If material is not included in the article's Creative Commons licence and your intended use is not permitted by statutory regulation or exceeds the permitted use, you will need to obtain permission directly from the copyright holder. To view a copy of this licence, visit http://creativecommons.org/licenses/by/4.0/.

Publisher's Note Springer Nature remains neutral with regard to jurisdictional claims in published maps and institutional affiliations.

The original article can be found online at https://doi.org/10.1007/ s00158-021-03107-7.

Eero Immonen

eero.immonen@turkuamk.fi

1 Computational Engineering and Analysis Research Group, Turku University of Applied Sciences, 20520 Turku, Finland 